\title{
In vitro Antibacterial, Antioxidant and Anti-Inflammatory Effects of Senecio asperulus and Gunnera perpensa from Mohale's Hoek, Lesotho
}

\author{
Mfengwana Polo-Ma-Abiele $\mathrm{H}^{1}{ }^{*}$, Mashele Samson $\mathrm{S}^{2}$, Manduna Idah $\mathrm{T}^{3}$
}

\section{Mfengwana Polo-Ma-Abiele $\mathrm{H}^{1, *}$, Mashele Samson $\mathrm{S}^{2}$, Manduna Idah $\mathrm{T}^{3}$}

'Department of Health Sciences, Central University of Technology, Free State, Private Bag X20539, Bloemfontein, 9300, SOUTH AFRICA.

2Unit for Drug Discovery Research, Central University of Technology, Free State, Private Bag X20539, Bloemfontein, 9300, SOUTH AFRICA.

${ }^{3}$ Centre for Applied Food Security and Biotechnology, Central University of Technology, Free State, Private Bag X20539, Bloemfontein, 9300, SOUTHAFRICA.

\section{Correspondence}

Polo-Ma-Abiele Hildah Mfengwana

R216, Ellen Khuzwayo Building, Department of Health Sciences, Central University of Technology, Free State, Bloemfontein, 9301, SOUTH AFRICA. Phone no: +2751 5073345 ;

Fax: +2751 5073345 ;

E-mail: pntsoeli@cut.ac.za

History

- Submission Date: 22-11-2018;

- Review completed: 08-04-2019;

- Accepted Date: 25-04-2019.

DOI : 10.5530/pj.2019.11.116

Article Available online http://www.phcogj.com/v11/i4

\section{Copyright}

(C) 2019 Phcogj.Com. This is an openaccess article distributed under the terms of the Creative Commons Attribution 4.0 International license.

\begin{abstract}
Background: Traditional medicinal plants have been widely used to treat or manage various ailments for centuries in Lesotho. With an increase in multi drug resistance and undesired adverse events to current drugs challenges, there is a need for alternative drugs. Aim: In this study we aimed at the investigation of antibacterial, antioxidant and anti-inflammatory effects of Senecio asperulus and Gunnera perpensa roots extracted in three solvents of different polarities. Materials and Methods: Antibacterial activity was determined using the disc diffusion method, while antioxidant activity was determined using free radical scavenging of 2,2-diphenyl-1-picrylhydrazyl and the ferric reducing antioxidant power assay. The Lipopolysaccharide (LPS) stimulated RAW 264.7 mouse macrophage in vitro model was used to evaluate the anti-inflammatory activity of both plants. Resveratrol was used as a positive control. Results: Methanol extracts of Senecio asperulus inhibited microbial growth even at the lowest concentration of $50 \mu \mathrm{g} / \mathrm{ml}$. Senecio asperulus dichloromethane extract was active on most bacteria with MIC's between $50 \mu \mathrm{g} / \mathrm{ml}$ and $500 \mu \mathrm{g} / \mathrm{ml}$. However, the water and methanol extracts of Gunnera perpensa had no activity against all organisms tested. Aqueous extracts of Senecio asperulus and Gunnera perpensa showed free radical scavenging activity yielding $\mathrm{EC}_{50}$ values of $100 \mu \mathrm{g} / \mathrm{ml}$ and $25 \mu \mathrm{g} / \mathrm{ml}$, respectively. The aqueous extracts of Senecio asperulus showed moderate anti-inflammatory activity from 50 to $200 \mu \mathrm{g} / \mathrm{ml}$. while the methanol extract was at $200 \mu \mathrm{g} / \mathrm{ml}$ and with no cytotoxicity. No anti-inflammatory activity was observed from all Gunnera perpensa extracts using LPS-induced macrophages, this suggests that this species may be using other mechanisms for anti-inflammatory activity. Conclusion: The antibacterial, antioxidant and anti-inflammatory activities observed from water extracts of Senecio asperulus support its ethnomedicinal use for the management of inflammation related diseases.

Key words: Antibacterial activity, Antioxidant activity, Anti-inflammatory activity, Senecio asperulus, Gunnera perpensa, Medicinal plants.

key messages:In Mohale's Hoek, Lesotho, Senecio asperulus and Gunnera perpensa are used for the treatment or management of various ailments especially since access to western health care facilities is limited. We are reporting on the efficacy of Senecio asperulus aqueous and methanol extracts as good candidates for potent novel anti-inflammatory, multi-drug resistant bacteria and antioxidant drugs development, as they had no cytotoxicity effects on tested RAW 264.7 cells. It is important to validate the ethnopharmacology and pharmacognosy of crude extract instead of isolated compounds as most active ingredients from medicinal plants work in synergy, hence crude extracts were used in this study.
\end{abstract}

\section{INTRODUCTION}

Inflammation is the protective response to injury of body cells and tissues due to exposure to various factors like infections, chemicals, heat and mechanical injuries. Chronic inflammation could be considered the basis of disease and this is a typical feature of many chronic disorders. Infections by organisms which are resistant to killing and clearing by the body, tend to cause chronic inflammation. Cell walls of gram-negative bacteria have lipopolysaccharides (LPS), which are endotoxins that have the ability to cause inflammation. The host response to LPS is known to be mediated by reactive oxygen species (ROS) as they lead to Rac activation and IL-1 expression, which are required to induce inflammation response. ${ }^{1-3}$ Excessive reactive oxygen species are closely involved in various human diseases such as inflammation, cancer, heart disease, aging, atherosclerosis, rheumatoid arthritis and Alzheimer's disease. Antioxidants have an ability to neutralize excessive ROS which can induce the oxidative stress that causes cell damage and culminates in inflammation.

Although inflammation is usually associated with a protective or healing response, many chronic diseases are characterised by persistent/chronic inflammation ultimately resulting in tissue dysfunction. The inflammation process triggers the release of mediators; histamine, kinins and prostaglandins, by damaged tissues which in

Cite this article: Mfengwana Polo-Ma-Abiele H, Mashele Samson S, Manduna Idah T. In vitro Antibacterial, Antioxidant and Anti-Inflammatory Effects of Senecio asperulus and Gunnera perpensa from Mohale's Hoek, Lesotho. Pharmacog J. 2019;11(4):730-9 
turn involves cell membrane alterations, vascular permeability and increased protein denaturation. ${ }^{4}$ Inflammation mediators are released as a result of induced cyclooxygenase 2 (COX-2), nitric oxide (NOS) and lipoxygenase (LP). Most non-steroidal anti-inflammatory drugs inhibit pathways that lead to the generation of inflammation mediators and this is essential for the treatment of inflammation. A good nonsteroidal anti-inflammatory drug (NSAIDs) acts through the inhibition of induced nitric oxide synthase (iNOS), which is a key enzyme for the generation of nitic oxide (NO) and cyclooxygenase (COX) isozymes. There is dissatisfaction with existing anti-inflammatory drugs, as they impose toxicity and adverse side effects, particularly affecting the gastrointestinal and cardiovascular systems. ${ }^{5}$ Moreover, they lead to much dependence on them, as disorders reoccur after treatment has been discontinued. The bad side effects from the synthetic antiinflammation drugs that are currently available have triggered a global trend of returning to natural sources of medicines. Thus, there is a significant increase in scientific and commercial interest in the discovery of new anti-inflammatory therapeutic and preventative agents from natural product sources.

Medicinal plants play a vital role in Lesotho's primary healthcare system as they are components of the most diverse and oldest African therapeutic systems. People in Lesotho use medicinal plants for selfmedication and they can diagnose and treat minor ailments without even consulting a traditional doctor or herbalist. ${ }^{6}$ This occurs particularly in remote rural areas with limited access to health facilities. Local people in these areas rely on a variety of medicinal plants such as Senecio asperulus and Gunnera perpensa to manage different ailments including inflammation related diseases. ${ }^{7,8}$ Senecio asperulus is a member of the Asteraceae family and is known as Moferefere or Letapisa by the Basotho people in Lesotho. Gunnera perpensa known as Qobo belongs to the Gunneraceae family. The dried roots of both plants are extensively used, independently or as a mixture with other medicinal plants, to treat a variety of ailments. Their uses include, but not limited to; colds and flu, urinary tract infections, sexual transmitted diseases, reproductive healthcare, umbilical cord inflammation, as vasodilating agents and circulation improvers. ${ }^{8,9}$ However, there is limited scientific data to validate these ethnobotanical claims is scarce. Thus, this study was carried out to validate and justify the traditional claims for the use of Qobo and Moferefere in the treatment of inflammation related diseases.

\section{METHODS AND MATERIALS}

\section{Plant collection}

The study received a plant collection and export permit from the Ministry of Tourism Environment and culture, Lesotho and import approval (NC.553/2017) from The Department of Economic Development, Tourism and Environmental Affairs, South Africa. Plant material was collected from the mountains of Lesotho (Mohale's Hoek district) and authenticated by scientists at the National Botanical Gardens in Bloemfontein, South Africa where voucher specimens, PHM01 for Senecio asperulus and PHM02 for Gunnera perpensa were deposited.

\section{Preparation of plant extracts}

The roots of both plant species were washed, air dried at room temperature and then ground into fine powder using an electric blender. The powdered roots of Senecio asperulus and Gunnera perpensa were soaked separately with distilled water $\left(\mathrm{DH}_{2} \mathrm{O}\right)$, methanol $(\mathrm{MeOH})$ and dichloromethane (DCM) for $72 \mathrm{~h}$ with occasional stirring. After filtration, the aqueous extracts were freeze dried and the organic solvent extracts were concentrated with rocket evaporator. Thereafter, the extracts were reconstituted in dimethyl sulphoxide (DMSO) to give a final concentration of $100 \mathrm{mg} / \mathrm{mL}$ respectively. Stock solutions were sonicated were solubility was an issue. All samples were then stored at $4^{\circ} \mathrm{C}$.

\section{Cell culture}

The mouse macrophage cell line, RAW 264.7 were cultured and maintained in RAW 264.7 growth medium 1 (RAWGM1) at $37^{\circ} \mathrm{C}$ in a humidified atmosphere with 5\% $\mathrm{CO}_{2}$. Suspensions of RAW 264.7 monolayer culture were seeded into 96 well microtiter plates at a density of 25,000 cells per well using a volume of $50 \mu \mathrm{l}$ in each well. The microtiter plates were then incubated at $37^{\circ} \mathrm{C}, 5 \% \mathrm{CO}_{2}$ and $100 \%$ relative humidity for $24 \mathrm{~h}$ prior to addition of test compounds to allow for cell attachment. The culture medium was then removed and the samples were added to give final concentrations of 12.5 and $50 \mu \mathrm{M}$.

\section{Microorganisms}

The American Type Culture Collection (ATCC) microorganisms used in this study were obtained from the Pathcare microbiology laboratory in Welkom South Africa. Four Gram positive bacteria (Staphylococcus aureus ATCC BAA-1026, Staphylococcus saprophyticus ATCC BAA750, Enterococcus faecalis ATCC 29212 and Streptococcus pneumoniae ATCC 49619) and four Gram negative bacteria (Enterobacter cloacae ATCC 700323, Escherichia coli ATCC 25922, Proteus mirabilis ATCC 35659 and Klebsiella pneumoniae ATCC 700603) were inoculated onto Muller-Hinton ( $\mathrm{MH})$ agar and later used in this study. All bacterial suspensions were prepared using sterile saline to obtain an optical density comparable to the density of $0.5 \mathrm{McF}$ arland barium sulphate standard (turbidity $=108 \mathrm{CFU} / \mathrm{mL}$ ).

\section{Phytochemical screening assay}

The qualitative phytochemical screening for the presence of flavonoids, tannins, saponins, terpenoids and alkaloids was carried out following methods by Shanmugam et al. ${ }^{10}$

\section{In vitro antibacterial assay}

The antibacterial activity was conducted using the disc diffusion method as adopted from Thitilertdecha et al. ${ }^{11}$ and Su et al. ${ }^{12}$ To determine the minimum inhibition concentration (MIC) of each plant extract, selected Gram positive and Gram-negative micro-organisms where treated with 4 concentrations of plant extracts from serial dilution namely: $1 \mathrm{mg} / \mathrm{ml}, 0.5 \mathrm{mg} / \mathrm{ml}, 0.25 \mathrm{mg} / \mathrm{ml}$ and $0.125 \mathrm{mg} / \mathrm{ml}$. After serial dilutions were prepared, $6 \mathrm{~mm}$ filter paper discs were impregnated with the extract at each concentration. The extract-loaded discs were then placed on the surface of the agar inoculated with different microorganisms as mentioned previously. Plates were incubated aerobically at $37^{\circ} \mathrm{C}$ and zones of inhibition were measured after $24 \mathrm{~h}$. The zones of inhibition were measured in $\mathrm{mm}$ using a calliper and the lowest concentration at which growth inhibition resulted was considered as minimum inhibition concentration (MIC). Discs (6 $\mathrm{mm}$ filter paper discs) dipped in DMSO were used as negative controls, while commercial chloramphenicol discs $(25 \mu \mathrm{g})$ and ampicillin $(10 \mu \mathrm{g})$, were used as positive controls. The tests were performed in triplicates and mean was calculated and reported.

\section{In vitro anti-oxidant assay}

The DPPH (2,2-diphenyl-1picrylhyrazyl) free radical scavenging assay was performed using a method by Najafabad and Jamei. ${ }^{13}$ Two hundred micro-litres $(200 \mu \mathrm{L})$ of $0.1 \mathrm{mM}$ DPPH prepared in methanol was added to $100 \mu \mathrm{L}$ of the plant extract diluted in different concentrations. The mixture was incubated in the dark at room temperature for $30 \mathrm{~min}$. Absorbance was then measured at $517 \mathrm{~nm}$. Ascorbic acid was used as a positive control. The experiments were performed in triplicates and percentage inhibition of the DPPH radical scavenging activity was calculated using the formula: 
$\%$ Inhibition $=\left(\left(\mathrm{Ac}-\mathrm{A}_{1}\right) / \mathrm{Ac}\right) \mathrm{X} 100$

Where $A c$ is the absorbance of the control and $A_{1}$ is the absorbance of the sample.

\section{Estimation of reducing power}

The reducing power of the plant extracts was estimated using the method by Najafabad and Jamei, ${ }^{13}$ whereby $500 \mu \mathrm{l}$ of $0.2 \mathrm{M}$ phosphate buffer (pH-6.6), $500 \mu \mathrm{l}$ of ferricyanide ( $1 \% \mathrm{w} / \mathrm{v})$ were mixed with $200 \mu \mathrm{l}$ of each extract and the mixture was then incubated for $20 \mathrm{~min}$ at $50^{\circ} \mathrm{C}$. After incubation, $500 \mu \mathrm{l}$ of TCA $(10 \% \mathrm{w} / \mathrm{v})$ was added to the extract mixture and centrifuged for $10 \mathrm{~min}$ at $3000 \mathrm{rpm}$. Thereafter, $500 \mu \mathrm{l}$ of the supernatant was collected using an automated pipette and added to $500 \mu \mathrm{l}$ of distilled water together with $100 \mu \mathrm{l}$ of ferric chloride $(0.1 \%$ $\mathrm{w} / \mathrm{v}$ ) and mixed thoroughly. Absorbance was then measured at $700 \mathrm{~nm}$ wavelength. Percentage inhibition was calculated for the determination of reducing power:

\section{$\%$ Inhibition $=\left(\mathrm{Ac}_{\mathrm{C}} \mathrm{A}_{1}\right) / \mathrm{Ac} \mathrm{X} 100$}

Where $A_{1}$ is the absorbance of the sample, $A c$ is the absorbance of control.

\section{Determination of anti-inflammatory activity in RAW 264.7 macrophages}

To assess the anti-inflammatory activity of the plant extracts, $50 \mu \mathrm{l}$ of Lipopolysaccharide (LPS) containing medium was added to the 96-wells plates with RAW 264.7 treated with plant extracts (as mentioned above under cell culture). Cells were then incubated for $20 \mathrm{~h}$. To quantify nitric oxide (NO) production, $50 \mu \mathrm{l}$ of the above culture medium with LPS was transferred to a new 96-well plate and $50 \mu$ l Griess reagent added. Absorbance was then measured at $540 \mathrm{~nm}$ wavelength and the results were expressed relative to the appropriate untreated control. A wellknown inhibitor of Inducible nitric oxide synthase (iNOS) expression, resveratrol, was used as a positive control.

\section{MTT assay}

To confirm that toxicity was not a contributory factor for antiinflammatory activity, cell viability was assessed using the MTT (3-(4, 5-dimethyl thiazol-2yl)-2, 5-diphenyl tetrazolium bromide) assay. ${ }^{14}$ RAW 264.7 cells were seeded in a 96 well microtiter plates at a density of 25,000 cells per well using a volume of $50 \mu \mathrm{l}$ in each well and allowed to adhere for $24 \mathrm{~h}$ at $37^{\circ} \mathrm{C}$ in a $\mathrm{CO}_{2}$ incubator. Media was then carefully aspirated from adherent cell cultures, discarded and replaced with fresh media. Cells were then treated with various concentrations of the plant extracts and re-incubated for $24 \mathrm{~h}$ at $37^{\circ} \mathrm{C}$. After incubation, the culture media was aspirated again and replaced with equal volumes of fresh media and MTT working solution $(5 \mathrm{mg} / \mathrm{mL}$ in phosphate buffer solution). Plates were then incubated further for $4 \mathrm{~h}$ at $37^{\circ} \mathrm{C}$. The media with MTT was removed and $100 \mu \mathrm{l}$ of DMSO solution was added into each well to solubilize the formed MTT formazan crystals (purple colour). Absorbance was measured at $570 \mathrm{~nm}$ wavelength and cell inhibition percentage was determined using the formula:

Percentage Cell Inhibition $=[100-$ Abs (sample) $/$ Abs (control) $]$ X 100.

\section{Statistical analysis}

All assays were performed in triplicate in all independent and separate experiments. The data is presented as means \pm SD from three independent analyses and separate experiments. One-way analysis of variance (ANOVA) was applied to determine the statistical significance in various anti-inflammatory and cytotoxicity markers level between the control and the tested samples. Microsoft EXCEL software was used. The level of significance will be set at 0.05 and 0.01 .

\section{RESULTS AND DISCUSSION}

\section{Phytochemical analysis}

Phytochemicals are naturally produced by plants for their protection and as a defence mechanism against microbes and insects. These phytochemicals can either be primary compounds such as, chlorophyll, proteins and common sugars, or be secondary compounds such as terpenoids, alkaloids, flavonoids, reducing sugars, tannins and phenols. ${ }^{15}$ Secondary metabolites are known to have important medicinal benefits to humans. ${ }^{16}$ Moreover, many studies have proved the diverse pharmacological activities of terpenoids as anti-bacterial, anti-oxidant, anti-inflammatory, anticancer, anti-viral, anti-malarial and anaesthetic agents. ${ }^{17-20}$ Geographical properties, natural conditions and bioconstituents of soil, does influence quality of secondary metabolites. ${ }^{21,22}$ This is indeed true, as Senecio asperulus collected from Mohale's Hoek, Lesotho (more rural area) was found to be rich in secondary metabolites when compared with phytochemistry findings by Mugomeri et al. ${ }^{7}$ using the same plant but collected from Maseru, Lesotho (which is the capital city of the Basotho country). However, our findings corroborated with Mugomeri et al. ${ }^{7}$ findings as Senecio asperulus methanol extracts had flavonoids, of which the aqueous extracts of the same plant showed no presence of flavonoids. This simply means that Senecio asperulus methanolic extracts contain flavonoids, regardless of their point of collection. From our results, terpenoids were present from all extracts of both plant species, extracted in different solvents, thus supporting the traditional medicinal values of these plants (Table 1). Aqueous extracts of Senecio asperulus showed the presence of more phytochemicals when compared to methanolic and dichloromethane extracts of the same plant species. Gunnera perpensa water extracts showed only the presence of flavonoids, terpenoids and tannins. However, its methanolic and dichloromethane extracts revealed the presence of almost all investigated phytochemicals (Table 1). This discovery indicates that active ingredients from this plant are more hydrophobic thus extracted better with solvents which are nonpolar.

\section{Antibacterial activity}

To determine the antibacterial activity and minimum inhibitory concentration (MIC) of each plant extract, selected Gram-positive and Gram-negative micro-organisms where treated with different concentrations of plant extracts. The zone of inhibition was measured and compared to that of controls. Two known antibiotics namely; ampicillin (for the Gram-positive organisms) and chloramphenicol (for the Gram-negatives) were used as positive controls, while saline was used as a negative control. MIC of each active extracts were presented in Table 2. Antibacterial bioactive plant compounds affect the integrity of the bacterial cell wall permeability so the bacteria leak to death, thus, inhibiting bacterial growth. ${ }^{23}$ The methanolic extracts of both Senecio asperulus and Gunnera perpensa failed to inhibit the growth of the Gram positive and negative microorganisms selected for this study even at higher concentrations of $500 \mu \mathrm{g} / \mathrm{ml}$, except for S. faecalis (Table 2). The most active plant extract was Senecio asperulus aqueous extract as it managed to inhibit growth of all strains tested against. Gunnera perpensa dichloromethane extracts also inhibited most microorganisms and only one organism (S. faecalis) was resistant even at the highest concentration. The antibacterial activity of (Senecio asperulus aqueous extract and Gunnera perpensa dichloromethane extract) relates bioactivity to the phytochemical content (Tables 1 and 2).

Minimum inhibition concentration (MIC) required to inhibit $S$. faecalis was $500 \mu \mathrm{g} / \mathrm{ml}$ for Senecio asperulus methanol extract and 50 $\mu \mathrm{g} / \mathrm{ml}$ for the aqueous and DCM extracts. Aqueous extracts further showed MIC to be $50 \mu \mathrm{g} / \mathrm{ml}$ for most tested Gram-negative's and Grampositive's, except for $S$. aureus and S. saprophyticus, as their MIC's were at $100 \mu \mathrm{g} / \mathrm{ml}$ and $250 \mu \mathrm{g} / \mathrm{ml}$, respectively (Table 2). Senecio asperulus 
Table 1: Phytochemical screening analysis of Senecio asperulus and Gunnera perpensa. (+) Indicate the presence and degree (due to color intensity) of phytochemicals and (-) Indicate the absence of phytochemicals.

\begin{tabular}{lcccccc}
\hline Plant extract & Flavonoids & Tannins & Saponins & Terpenoids & Steroids & Alkaloids \\
\hline Senecio asperulus $(\mathrm{MeOH})$ & ++ & ++ & - & + & + & + \\
Senecio asperulus $\left(\mathrm{H}_{2} \mathrm{O}\right)$ & - & + & + & + & + & + \\
Senecio asperulus $(\mathrm{DCM})$ & + & - & - & ++ & + & + \\
Gunnera perpensa $(\mathrm{MeOH})$ & + & + & + & ++ & - & + \\
Gunnera perpensa $\left(\mathrm{H}_{2} \mathrm{O}\right)$ & +++ & + & - & + & - & + \\
Gunnera perpensa $(\mathrm{DCM})$ & +++ & - & + & ++ & + \\
\hline
\end{tabular}

Table 2: Antibacterial analysis of Senecio asperulus and Gunnera perpensa.

\begin{tabular}{|c|c|c|c|c|c|c|c|c|c|}
\hline Micro-organisms & Concentration $(\mu \mathrm{g} / \mathrm{ml})$ & S1 & S2 & S3 & G1 & G2 & G3 & Control A & Control B \\
\hline \multirow{4}{*}{ S. faecalis } & 500 & + & ++ & + & - & - & - & \multirow{4}{*}{++} & \multirow{4}{*}{-} \\
\hline & 250 & - & + & + & - & - & - & & \\
\hline & 100 & - & + & + & - & - & - & & \\
\hline & 50 & - & + & + & - & - & - & & \\
\hline \multirow{4}{*}{ S.pneumoniae } & 500 & - & + & - & - & - & + & \multirow{4}{*}{++} & \multirow{4}{*}{-} \\
\hline & 250 & - & + & - & - & - & + & & \\
\hline & 100 & - & + & - & - & - & + & & \\
\hline & 50 & - & + & - & - & - & + & & \\
\hline \multirow{4}{*}{ P.mirabilis } & 500 & - & ++ & + & - & - & ++ & \multirow{4}{*}{-} & \multirow{4}{*}{++} \\
\hline & 250 & - & + & + & - & - & + & & \\
\hline & 100 & - & + & + & - & - & + & & \\
\hline & 50 & - & + & + & - & - & - & & \\
\hline \multirow{4}{*}{ K.pneumoniae } & 500 & - & ++ & + & - & - & ++ & \multirow{4}{*}{-} & \multirow{4}{*}{++} \\
\hline & 250 & - & + & + & - & - & ++ & & \\
\hline & 100 & - & + & + & - & - & + & & \\
\hline & 50 & - & + & + & - & - & + & & \\
\hline \multirow{4}{*}{ S.saprophyticus } & 500 & - & + & - & - & - & + & \multirow{4}{*}{++} & \multirow{4}{*}{-} \\
\hline & 250 & - & + & - & - & - & + & & \\
\hline & 100 & - & - & - & - & - & + & & \\
\hline & 50 & - & - & - & - & - & + & & \\
\hline \multirow{4}{*}{ S.aureus } & 500 & - & + & - & - & - & + & \multirow{4}{*}{++} & \multirow{4}{*}{ - } \\
\hline & 250 & - & + & - & - & - & + & & \\
\hline & 100 & - & + & - & - & - & - & & \\
\hline & 50 & - & - & - & - & - & - & & \\
\hline \multirow{4}{*}{ E. coli } & 500 & - & + & + & - & - & + & \multirow{4}{*}{-} & \multirow{4}{*}{++} \\
\hline & 250 & - & + & + & - & - & + & & \\
\hline & 100 & - & + & + & - & - & + & & \\
\hline & 50 & - & + & - & - & - & + & & \\
\hline \multirow{4}{*}{ E.cloacae } & 500 & - & + & + & - & - & ++ & \multirow{4}{*}{ - } & \multirow{4}{*}{++} \\
\hline & 250 & - & + & - & - & - & + & & \\
\hline & 100 & - & + & - & - & - & + & & \\
\hline & 50 & - & + & - & - & - & + & & \\
\hline
\end{tabular}

Abbreviations: S1: Senecio asperulus methanol extract; S2: Senecio asperulus aqueous extract; S3: Senecio asperulus dichloromethane extract; G1: Gunnera perpensa methanol extract; G2: Gunnera perpensa aqueous extract; G3: Gunnera perpensa dichloromethane extract; $[++]$ : sensitive with zone of inhibition $\geq 16 \mathrm{~mm} ;[+]$ : sensitive with zone of inhibition $\leq 16$ $\mathrm{mm} ;[-]$ : resistant with no zone of inhibition. Control A: Ampicillin; Control B: Chloramphenicol. MIC of each active extracts are presented with "Bold" cross signs (+) and yellow colouring. 
further showed the MIC to be at $50 \mu \mathrm{g} / \mathrm{ml}$ for $S$. faecalis, $P$. mirabilis and $K$. pneumoniae and at $100 \mu \mathrm{g} / \mathrm{ml}$ for E. coli. E. cloacae resisted the DCM extract on all other concentrations, besides the highest tested concentration of $500 \mu \mathrm{g} / \mathrm{ml}$, however, the zone of inhibition was $>16$ $\mathrm{mm}$. Gunnera perpensa DCM extract was very active with the MIC of $50 \mu \mathrm{g} / \mathrm{ml}$ for most organisms, besides $P$. mirabilis and $S$. aureus as their MIC's were $100 \mu \mathrm{g} / \mathrm{ml}$ and $250 \mu \mathrm{g} / \mathrm{ml}$, respectively (Table 2 ).

\section{Anti-oxidant activity}

Biological oxidant reactions of exogenous and endogenous factors generate active oxygen species or oxidants such as free radicals in a human body. Unfortunately, these unstable produced oxidants give rise to oxidative stress and are found to be responsible for many diseases due to their ability to cause DNA damage. Phenols have redox properties which acts as hydrogen donors, oxygen quenchers and reducing agents, thus, delocalize the unstable and unpaired electron within the aromatic structure. ${ }^{24}$ Antioxidants from natural sources are important in safeguarding human health and as protection from diseases resulting from oxidative stress. Phytochemical antioxidants such as flavonoids have an aptitude to reduce oxidative stress by neutralizing these reactive oxygen species. Moreover, natural antioxidants are considered to be more active and safer to health than synthetic antioxidants, as the latter turns to have detrimental side effects when used in vivo. ${ }^{17}$

The DPPH assay was used to investigate the free radical-scavenging activities of Senecio asperulus and Gunnera perpensa. Activities were expressed as percentages in order to determine plant extract concentration required to achieve a $50 \%$ DPPH scavenging activity $\left(\mathrm{EC}_{50}\right)$. The dose-dependent antioxidant activity of the tested extracts are summarized in Figure 1. The aqueous extract of Senecio asperulus had an $\mathrm{EC}_{50}$ of $100 \mu \mathrm{g} / \mathrm{ml}$ and managed to scavenge about 78\% DPPH at the highest concentration of $500 \mu \mathrm{g} / \mathrm{ml}$. Gunnera perpensa aqueous extract $\mathrm{EC}_{50}$ was observed at the lowest concentration of $25 \mu \mathrm{g} / \mathrm{ml}$, whereas ascorbic acid $\mathrm{EC}_{50}$ was only at $50 \mu \mathrm{g} / \mathrm{ml}$, which is two-folds. This was very impressive as it suggests Gunnera perpensa to be a very strong antioxidant agent.

The genus Senecio is known to be rich in flavonoids ${ }^{25}$ and Gunnera perpensa is the only species from the Gunnera genus which has flavonoids. ${ }^{26}$ Flavonoids are known to have very strong antioxidant activities. ${ }^{27,28}$ Tannins are known as water-soluble phenolic compounds and were present in both plant species aqueous extracts. According to Karamac' et al. ${ }^{29}$ tannins can chelate metal ions and interfere with the formation of hydroxyl free radicals, thus, cancels oxidation. There was a directly proportional relationship between the presence of both flavonoids and tannins and the antioxidant activity of Senecio asperulus methanol and Gunnera perpensa aqueous extracts. Thus, indicating that these phenols; flavonoids and tannins, were the leading contributors to the observed antioxidant activities.

The reduction capacity of a compound may serve as a significant indicator of its potential antioxidant activity as it proves the electron transfer ability of the extract. The reduction of oxidized intermediates of lipid peroxidation process was indicated by the formation of ferrous chloride and potassium ferrocyanide which produced a green to blue colour. The intensity of the formed colour was dependent on the reducing power of the extract used. Senecio asperulus and Gunnera perpensa aqueous and methanol extracts showed increased ferric reducing power with the increasing concentration as shown in Figure 2. The aqueous extracts from Gunnera perpensa proved to be a better source of antioxidants as their reducing power were $50 \%$ at $100 \mu \mathrm{g} /$ $\mathrm{ml}$, followed by the methanolic extracts as these extracts also showed increased reducing power. The dichloromethane extracts of both plants showed less reducing power than ascorbic acid and the other extracts. These results did indicate that Senecio asperulus and Gunnera perpensa have very strong free radical scavenging and antioxidant properties
(Figure 1) possibly due to their hydrogen donor ability as confirmed by the estimation of ferric reducing power.

\section{Anti-inflammatory activity}

Macrophages represent a highly heterogeneous group of hematopoietic cells present in almost all tissues including adipose. Moreover, they diversely perform complex microbicidal functions, such as; surveillance, chemotaxis, phagocytosis and destruction of pathogenic micro-organisms. Therefore, the development of therapeutics which can non-specifically enhance the innate immune response represents a promising strategy to combat classical and emerging infectious agents. ${ }^{30}$ However, depending on the trigger, macrophage responses can be divided into two distinct and mutually exclusive activation programs termed classical and alternative. Classical activation results in a highly inflammatory phenotype and mainly occurs in response to bacterial products such as lipopolysaccharides (LPS) and interferon gamma (IF- $\gamma)$. These classically activated macrophages produce a myriad of pro-inflammatory signals which can alter the functionality of its surrounding cells.

In addition, these activated cells produce various highly reactive oxidants including nitric oxide (NO), a product of the catalysis of arginine by the enzyme inducible nitric oxide synthase (iNOS). ${ }^{31}$ The mouse macrophage cell line, RAW 264.7, is a well characterised and popular model to investigate the anti-inflammatory potential of test samples. As cells were cultured in multi-well plates and activated by exposure to LPS which induces the expression of iNOS with concomitant nitric oxide formation. Changes in NO production were determined by measuring the levels of nitrate in the culture medium. Figure 3 illustrates the levels of nitrate macrophage cells produce nitrite and nitrate in response to LPS formed after macrophages were exposed to plant extracts.

High anti-inflammatory activity was observed from the DCM extract of Senecio asperulus, even when compared with the activity of the control. Senecio asperulus showed an ability to suppress NO production by down-regulating the expression of iNOS in RAW 264.7 macrophages. According to Chen et al. ${ }^{32}$ non-lectin glycoprotein (PCP-3A) inhibits LPS-induced production of NO through the down-regulation of iNOS via a transcription factor NF-JB mechanism. Thus, this could suggest that anti-inflammatory activity observed from Senecio asperulus (Figure 3) may be through this mechanism involving the transcription factor NF-JB, however, this remains to be elucidated through further investigations. Furthermore, it is known that LPS induces the expression of iNOS through redox-sensitive signalling pathways where superoxide anions act as second messengers. Antioxidants inhibit redox-active signalling by blocking radical producing enzymes. ${ }^{33}$ Thus, the antioxidant potential of this Senecio asperulus could be responsible for the observed anti-inflammatory activity.

Senecio asperulus methanol and aqueous extracts exhibited antiinflammatory potential, which was moderate when compared with that of the positive control, resveratrol. All Gunnera perpensa extracts showed no detectable inhibition, even at the highest concentration of $200 \mu \mathrm{g} / \mathrm{ml}$. This reported lipopolysaccharide induced anti-inflammatory activity assay was carried out simultaneous with the evaluation of cell viability (MTT assay) to confirm the absence of cytotoxicity of the test sample.

\section{Cell viability}

To confirm the absence of toxicity as a contributory factor, cell viability was assessed using MTT. The MTT assay is a colorimetric assay is used to reflect the number of viable cells present through the assessment of cell metabolic activity after treatment with test compounds. MTT, a yellow tetrazole, is reduced to purple formazan in living cells. ${ }^{34} \mathrm{~A}$ solubilization 

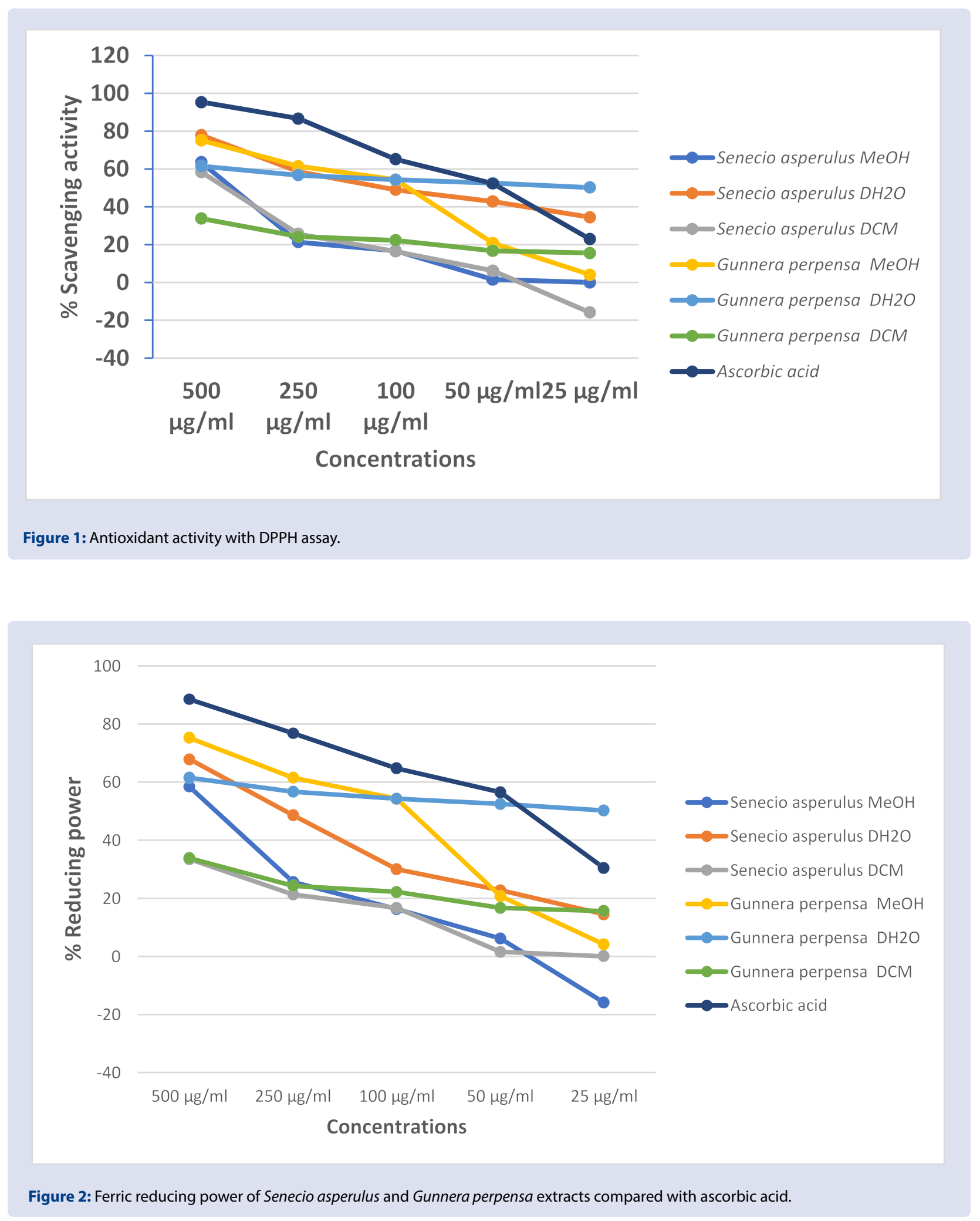


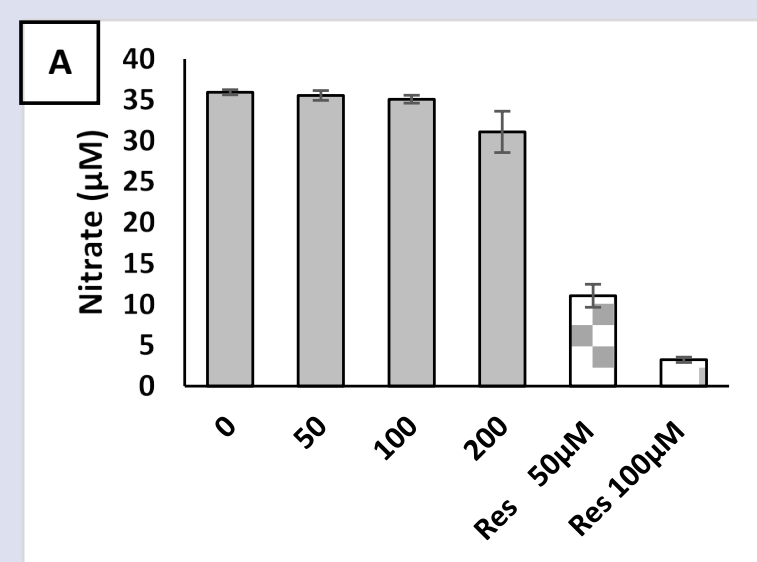

[Senecio asperulus $\mathrm{MeOH}](\mu \mathrm{g} / \mathrm{ml})$

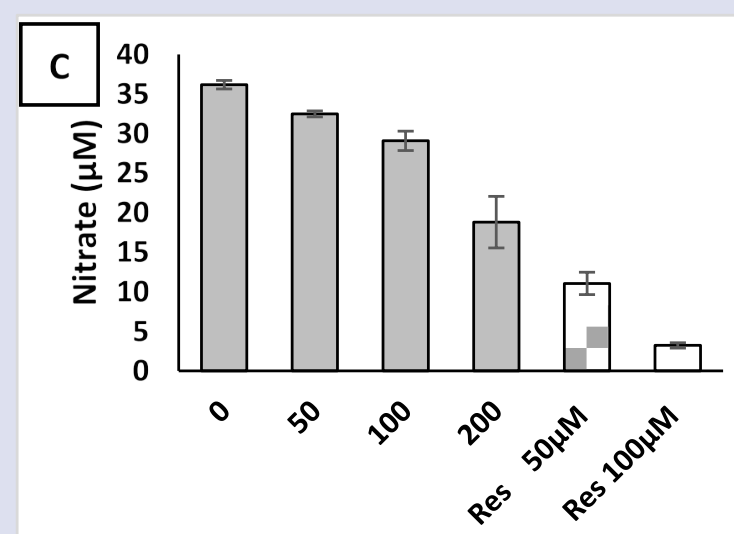

[Senecio asperulus $\left.\mathrm{DH}_{2} \mathrm{O}\right](\mu \mathrm{g} / \mathrm{ml})$

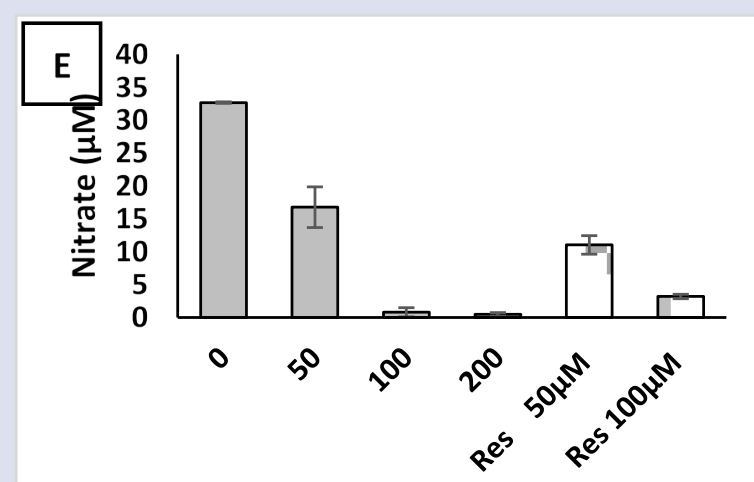

[Senecio asperulus DCM] ( $\mu \mathrm{g} / \mathrm{ml})$

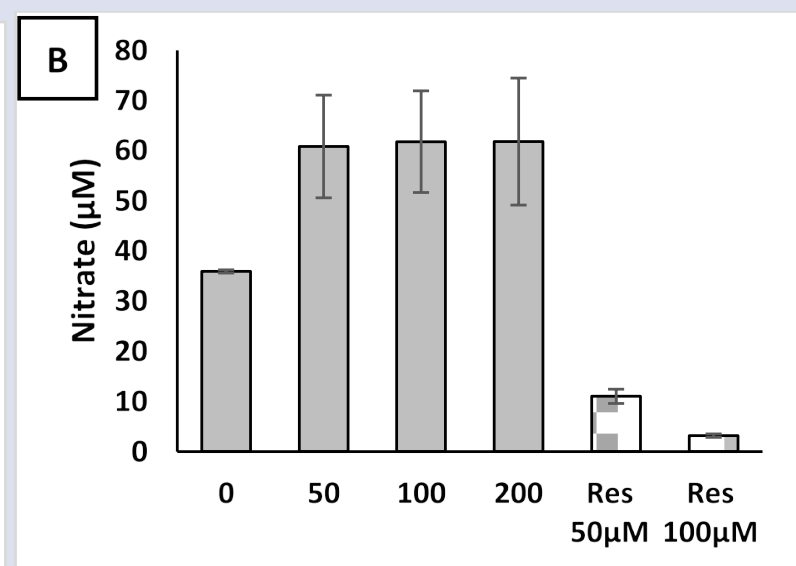

[Gunnera perpensa MeOH] $(\mu \mathrm{g} / \mathrm{ml})$

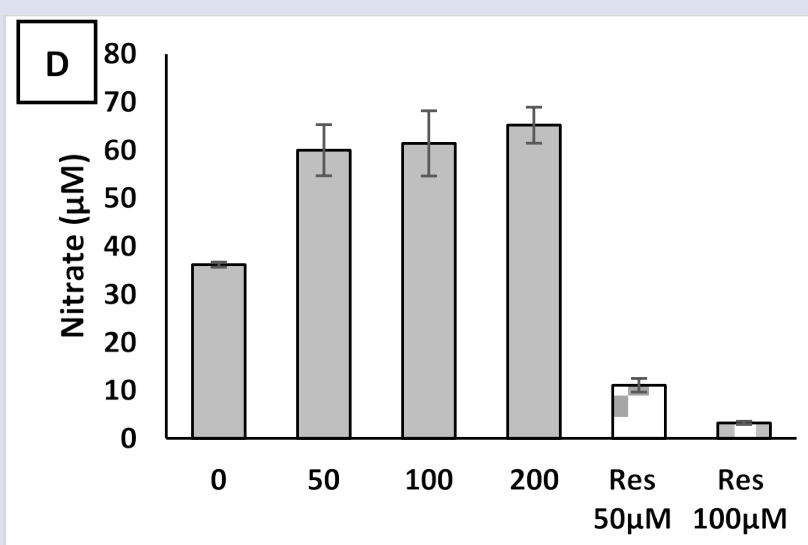

[Gunnera perpensa $\left.\mathrm{DH}_{2} \mathrm{O}\right](\mu \mathrm{g} / \mathrm{ml})$

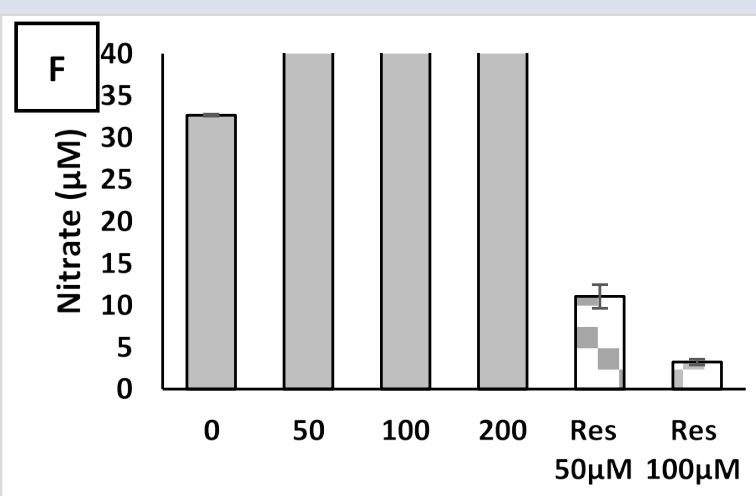

[Gunnera perpensa DCM] $(\mu \mathrm{g} / \mathrm{ml})$

Figure 3A-F: Nitric oxide production in LPS activated macrophages treated with different concentrations of Senecio asperulus and Gunnera perpensa extracts compared with resveratrol. 
solution is then added to dissolve the insoluble purple formazan product into a coloured solution. The absorbance of this coloured solution is quantified spectrophotometrically by measuring light absorbance at a wavelength of $600 \mathrm{~nm}$. The degree of light absorption depends on the solvent. $\mathrm{NAD}(\mathrm{P}) \mathrm{H}$-dependent oxidoreductase enzymes in the cytosolic compartment of the cell influences the reduction of tetrazolium dye. ${ }^{35}$ Thus, MTT reduction depends on the cellular metabolic activity due to $\mathrm{NAD}(\mathrm{P}) \mathrm{H}$ flux.
Methanol and aqueous extracts of Senecio asperulus showed no significant toxicity towards RAW 264.7 cells (Figures 4A and 4C). However, the toxicity of the DCM extract of Senecio asperulus did override the meaningful prediction of anti-inflammatory potential from Figure 3E. Thus, re-evaluation at lower concentrations below 50 $\mu \mathrm{g} / \mathrm{ml}$ may provide more conclusive decision however toxicity remains a potential risk for continual use of any medicine, not excluding natural medicinal plants.

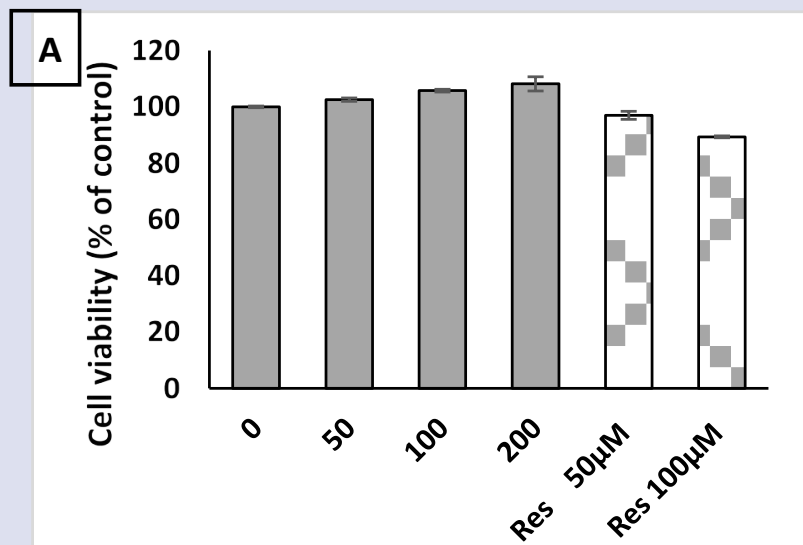

[Senecio asperulus $\mathrm{MeOH}](\mu \mathrm{g} / \mathrm{ml})$

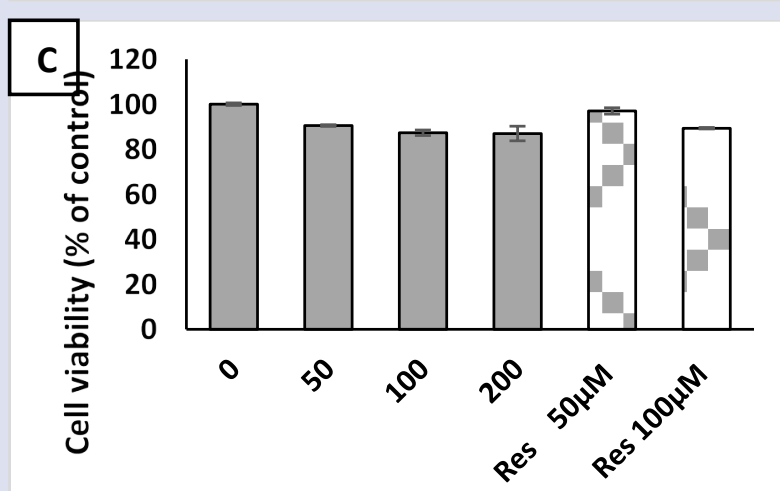

[Senecio asperulus $\mathrm{DH}_{2} \mathrm{O}$ ] $(\mu \mathrm{g} / \mathrm{ml})$

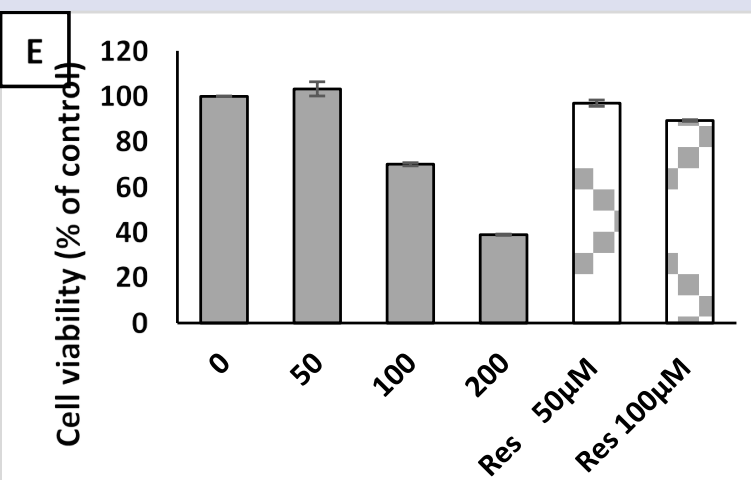

[Senecio asperulus DCM] ( $\mu \mathrm{g} / \mathrm{ml})$

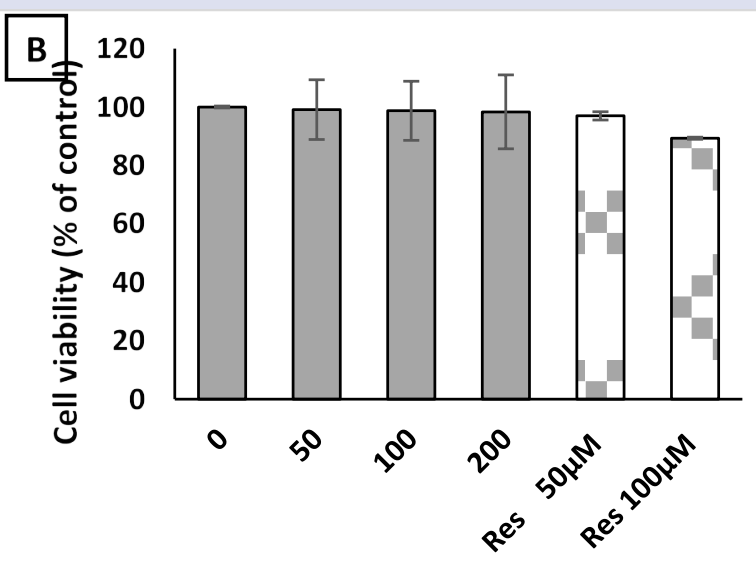

[Gunnera perpensa $\mathrm{MeOH}](\mu \mathrm{g} / \mathrm{ml})$

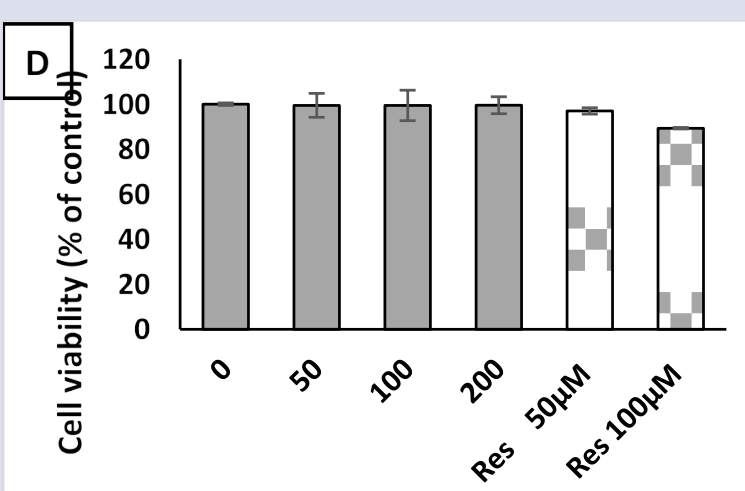

[Gunnera perpensa $\left.\mathrm{DH}_{2} \mathrm{O}\right](\mu \mathrm{g} / \mathrm{ml})$

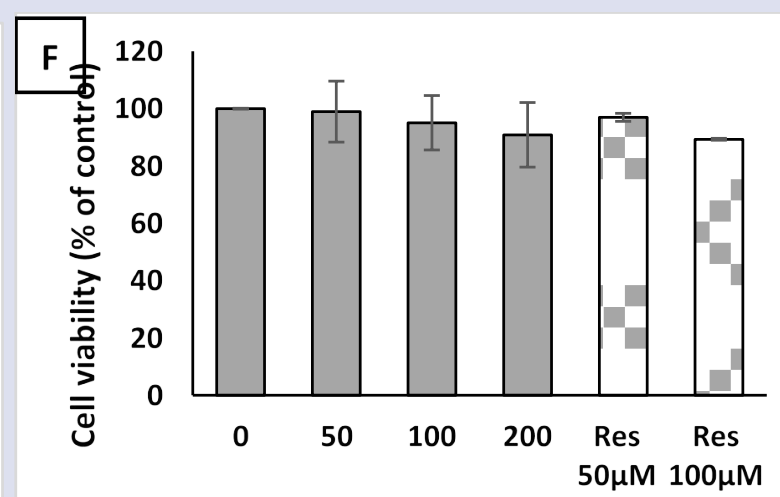

[Gunnera perpensa DCM] $(\mu \mathrm{g} / \mathrm{ml})$

Figure 4A-F: Cytotoxicity evaluation of Senecio asperulus and Gunnera perpensa different extracts. 


\section{CONCLUSION}

This study demonstrated that, Senecio asperulus and Gunnera perpensa are both rich in phytochemicals especially flavonoids, tannins, saponins and alkaloids. These phytochemicals are known for their pharmacological activities such as anti-oxidant, antidiabetic, antibacterial, antiviral, antiinflammatory, anti-diarrheal, hepatoprotective and radioprotective effects, amongst others. Thus, based on our results, we suggest that Senecio asperulus aqueous and methanol extracts can be good candidates for potent anti-inflammatory, multi-drug resistant bacteria and novel antioxidant drugs development, as they had no cytotoxicity effects on tested cells. Furthermore, our results validated the Basotho traditional medicinal use of Senecio asperulus and Gunnera perpensa for the treatment of inflammation related conditions and for the treatment of wounds (due to their antimicrobial, antioxidant and anti-inflammatory activity). However, further studies for the purification of bioactive compounds (so as to synthesise these active compounds in order to promote their conservation) and in vivo studies, are recommended for the evaluation of these active extracts as effective anti-inflammatory, antibacterial and antioxidant agents.

\section{ACKNOWLEDGEMENTS}

Authors would like to thank the Central University of Technology, Free State research office, NRF and DHET for their financial support. A thank you also goes to Bioassaix group, Nelson Mandela Metropolitan University, South Africa for assisting us with the experiments. We also express our genuine gratitude to the "Ha Morena Motlatsi's" Chieftaincy, Mpharane, Mohale's Hoek District, Lesotho for welcoming us with warmth and allowed us to collect plant materials from their land. Special thanks to our knowledge holder, Ms T.R Mochochoko for sharing her knowledge with us.

\section{CONFLICTS OF INTEREST}

No conflicts of interest to be declared by authors.

\section{SOURCE(S) OF SUPPORT}

Central University of Technology, Free State research office, NRF and DHET.

\section{ABBREVIATIONS}

$\mu \mathrm{L}$ : Microlitre; $\mu \mathrm{M}$ : Micromolar; ATCC: American Type Culture Collection; $\mathrm{CO}_{2}$ : Carbon dioxide; COX-2: Cyclooxygenase 2; DCM: Dichloromethane; DMSO: Dimethyl sulphoxide; DNA: Deoxyribonucleic acid; DPPH: 2,2-diphenyl-1picrylhyrazyl; $\mathrm{EC}_{50}$ : Half maximal effective concentration; IF- $\gamma$ : Interferon gamma; IL-1: interleukin-1; iNOS: induced nitric oxide synthesis; LP: lipoxygenase; LPS: lipopolysaccharides; $\mathrm{MeOH}$ : Methanol; MIC: minimum inhibition concentration; mM: Millimolar; MTT: 3-(4, 5-dimethyl thiazol-2yl)-2, 5-diphenyl tetrazolium bromide; nm: Nanometre; NOS: Nitric oxide; NSAIDs: Non-steroidal anti-inflammatory drug; ROS: reactive oxygen species; TCA: Trichloroacetic acid; w/v: Weight per volume.

\section{REFERENCES}

1. Hsu HY, Wen MH. Lipopolysaccharide-mediated reactive oxygen species and signal transduction in the regulation of interleukin-1 gene expression. $J$ Biol Chem. 2002;277(25):22131-9.

2. Hsu BG, Yang FL, Lee RP, Peng, TC, Harn, HJ, Chen HI. N-acetylcysteine ameliorates lipopolysaccharide-induced organ damage in conscious rats. J Biomed Sci. 2004;11:152-62.

3. Antonicelli F, Brown D, Parmentier M, Drost EM, Hirani, N, Rahm, D K, MacNee W. Regulation of LPS-mediated inflammation in vivo and in vitro by the thio antioxidant nacystelyn. Am J Physiol Lung Cell Mol Physiol. 2004;286:1319-27.

4. Leelaprakash GS, Mohan Dass SM. In vitro anti-inflammatory activity of methanol extract of Enicostemma axillare. Int J Drug Dev Res. 2011;3(3):189-96.
5. Brune, Patrignani. New insights into the use of currently available non-steroidal anti-inflammatory drugs. J Pain Res. 2015;8:105-18.

6. Moteetee A, Van Wyk B. The medical ethnobotany of Lesotho: A review Bothalia. 2011;41(1):209-28

7. Mugomeri E, Chatanga P, Hlapisi S, Rahlao L. Phytochemical characterization of selected herbal products in Lesotho. Lesotho Med Asso J. 2014;12:38-47.

8. Kose LS, Moteetee A, Van Vuuren S. Ethnobotanical survey of medicinal plants used in the Maseru district of Lesotho. J Ethnopharmacol. 2015;170:184-200.

9. Van der Merwe D, Swan GE, Botha CJ. Use of ethnoveterinary medical plants in cattle by Setswana-speaking people in the Madikwe area of the North West Province of South Africa. J S Afr Vet Assoc. 2001;72(4):189-96.

10. Shanmugam S, Sathish KT, Panneer SK. Laboratory handbook on Biochemistry. $2^{\text {nd }}$ ed. PHI Learning Pvt. Ltd; 2010.

11. Thitilertdecha N, Teerawutgulrag A, Rakariyatham N. Antioxidant and antibacterial activities of Nephelium lappaceum L. extracts. LWT-Food Sci Technol. 2008;41(10):2029-35

12. Su P, Yang C, Yang J, Su P, Chuang L. Antibacterial activities and antibacteria mechanism of polygonum cuspidatum extracts against nosocomial drugresistant pathogens. Molecules. 2015;20(6):11119-30

13. Najafabad AM, Jamei R. Free radical scavenging capacity and antioxidant activity of methanolic and ethanolic extracts of plum (Prunus domestica L.) in both fresh and dried samples. Avicenna J Phytomed. 2001;4(5):343-53.

14. Van Meerloo J, Kaspers GJL, Cloos J. Cell sensitivity assays: The MTT assay Methods Mol Biol. 2011;731:237-45

15. Abdul W, Mehreen G, Syed BJ, Muhammad N, Ajmal K, Rukhsana G, Asnad. Phytochemical analysis of medicinal plants occurring in local area of mardan. Biochem. Ana. Biochem. 2013;2(4):1-4.

16. Krishnaiah D, Rosalam S, Awang B. Phytochemical antioxidants for health and medicine A move towards nature. Biotechnol Mol Biol Rev. 2007;1(4):97-104.

17. Wagner $\mathrm{KH}$, Elmadfa I. Biological relevance of terpenoids: Overview focusing on mono-di and tetraterpenes. Ann Nutr Metab. 2003;47:95-106.

18. Kappers IF, Aharoni A, van Herpen TW, Luckerhoff LL, Dicke M, et al. Genetic engineering of terpenoid metabolism attracts bodyguards to Arabidopsis. Science. 2005;309:2070-2.

19. Rabi T, Bishayee A. Terpenoids and breast cancer chemoprevention. Breast Cancer Res Treat. 2009;115:223-39.

20. Negi JS, Singh P, Rawat B. Chemical constituents and biological importance of Swertia: A review. Curr Res Chem. 2011;3:1-15.

21. Inbathamizh L, Padmini E. Effects of geographical properties on the phytochemical composition and antioxidant potential of Moringa oleifera flowers. BioMedRx. 2013;1(3):239-47.

22. Santhi K, sengottuvel R. Qualitative and quantitative phytochemical analysis of Moringa concanensis nimmo. Int J Curr Microbiol App Sci. 2016;5(1):633-40.

23. Yildirim A, Mavi A, Kara AA. Determination of antioxidant and antimicrobial activities of Rumexcrispus L. extracts. J Agric Food Chem. 2001;49:4083-9.

24. Ross JA, Kasum CM. Dietary flavonoids: Bioavailability, metabolic effects and safety. Annu Rev Nutr. 2002;22:19-34.

25. Singh D, Satish CS, Manisha DS. Chemical and potential biological perspectives of genus Senecio [Asteraceae]. Eur J Pharm Med Res. 2017;4(11):200-22.

26. Maroyi A. From traditional usage to pharmacological evidence: Systematic review of Gunnera perpensa L. Evid Based Complement Alternat Med. 2016:14-25.

27. Hollman PCH. Evidence for health effects of plant phenols: Local or systemic effects? J Sci Food Agric. 2001;81:842-52

28. Nijveldt RJ, van Nood E, van Hoorn DE, Boelens PG, van Norren K, van Leeuwen PA. Flavonoids: A review of probable mechanisms of action and potential applications. Am J Clin Nutr. 2001;74(4):418-25.

29. Karamac' MA. Kosinska RA. Chelating of Fe(II), Zn(II) and $\mathrm{Cu}(\mathrm{II})$ by tannin fractions separated from hazelnuts, walnuts and almonds. Food Chem Toxicol. 2006;39:257-60

30. Mifsud EJ, Tan AC, Jackson DC. TLR agonists as modulators of the innate immune response and their potential as agents against infectious disease. Front Immunol. 2014;5:1-10.

31. Sangwon K and Prem P. Effects of interferon-g and lipopolysaccharide on macrophage iron metabolism are mediated by nitric oxide-induced degradation of iron regulatory protein 2. J Biol Chem. 2000;275(9):6220-6.

32. Chen JN, De Mejia EG, Wu JSB. Inhibitory effect of a glycoprotein isolated from golden oyster mushroom (Pleurotus citrinopileatus) on the lipopolysaccharideinduced inflammatory reaction in RAW 264.7 macrophage. J Agric Food Chem 2011;59(13):7092-7.

33. Jedinak A, Dudhgaonkar S, Wu Q, Simon J, Sliva D. Anti-inflammatory activity of edible oyster mushroom is mediated through the inhibition of NF-B and AP-1 signaling. Nutr J. 2011;10:52-9. 
34. Mosmann, T. Rapid colorimetric assay for cellular growth and survival: Application to proliferation and cytotoxicity assays. J Immunol Methods. 1983;65(1-2):55-63.
35. Berridge MV, Herst PM, Tan AS. Tetrazolium dyes as tools in cell biology: New insights into their cellular reduction. Biotechnol Annu Rev. 2005;11:127-52.

\section{SUMMARY}

The antibacterial and antioxidant activities observed from Senecio asperulus aqueous extracts and Gunnera perpensa dichloromethane extracts related with the phytochemical contents observed from these extracts as well as the antiinflammation activity of $S$. asperulus. To the best of the author's knowledge, there was no report on the anti-inflammation ability of $S$. asperulus roots extracts on lipopolysaccharide induced RAW 264.7 macrophages. This research study further provides evidence that antioxidants do suppress iNOS expression and subsequently nitric oxide production, thus inhibit inflammation. Moreover, these findings support the ethnomedicinal use of Senecio asperulus for the management of inflammation related diseases.

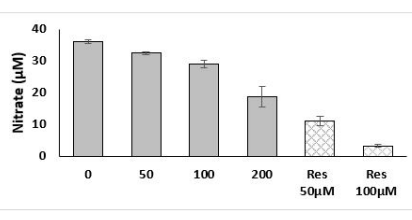

Moderate anti-inflammatory activity on RAW 264.7

\section{ABOUT AUTHORS}

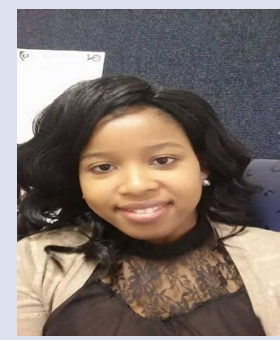

Polo-Ma-Abiele Hildah Mfengwana is the nGAP Lecturer in Biomedical Technology at the Central University of Technology, Free State, South Africa. She is passionate and proud of Africa's flora and fauna biodiversity thus her research focus is on the safety and efficacy of traditional medicinal plants used to treat cancer by traditional healers in Africa as well as in drug discovery from medicinal plants. Her previous research work has resulted in publications of papers in reputable international journals and she has presented her research findings in both national and international conferences and her research presentations were voted as the best presentations by students a number of times.

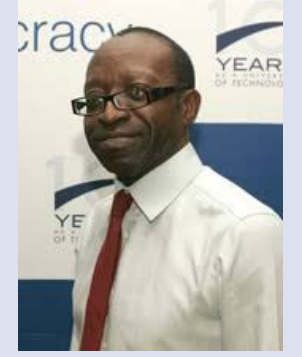

Prof. Mashele is currently the Dean of the Faculty of Health and Environmental Sciences. He is also the Director of the Drug Discovery Unit at CUT. He is serving on the editorial boards of many international journals and as panel member in research foundations. He has supervised many students and published extensively in high impact factor journals. His Drug Discovery Unit currently has more than 50 Masters and Doctoral students. His Unit's latest discovery saw widespread media coverage. He is collaborating with Universities overseas, the CSIR and the National Cancer Institute (USA). Prof Mashele has been nominated for the 'Who's who in the World' by International experts.

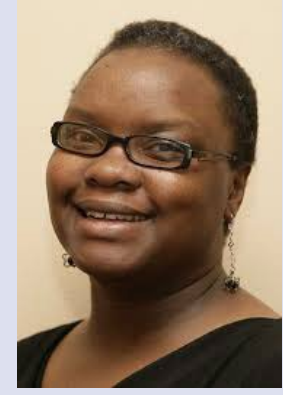

Dr. IT Manduna has a MSc in Botany (University of Fort Hare South Africa) and DSc in Botany from Colegio de Postgraduados (COLPOS, Mexico). She is an ethnobotanist with special interest in African traditional medicine and indigenous vegetables in terms of scientific validation, safety assurance and agro-processing. She has worked as a lecturer at Walter Sisulu University, South Africa and is currently a researcher in the Centre for Applied Food Sustainability and Biotechnology (Central University of Technology, South Africa).

Cite this article: Mfengwana Polo-Ma-Abiele H, Mashele Samson S, Manduna Idah T. In vitro Antibacterial, Antioxidant and AntiInflammatory Effects of Senecio asperulus and Gunnera perpensa from Mohale's Hoek, Lesotho. Pharmacog J. 2019;11(4):730-9 